\title{
ANALISIS PERDAGANGAN INTRA INDUSTRI REGIONAL COMPREHENSIVE ECONOMIC PARTNERSHIP (RCEP) PADA PRODUK PERTANIAN
}

\author{
Analysis of Intra-Industry Trade of Regional Comprehensive Economic \\ Partnership (RCEP) In Agricultural Products
}

\author{
Rahma Meiliza Putri ${ }^{1}$, Amzul Rifin $^{2}$, Erwidodo 2 \\ 1 Program Studi Agribisnis, Pascasarjana, Institut Pertanian Bogor \\ 2 Departemen Agribisnis, Fakultas Ekonomi dan Manajemen, Institut Pertanian Bogor \\ 1,2JI. Kamper-Kampus IPB Dramaga Bogor, Lantai 5, Bogor, Jawa Barat, 16680, Indonesia \\ Email: rahmameiliza@apps.ipb.ac.id
}

Naskah diterima: 04/03/2021; Naskah direvisi: 23/05/2021; Disetujui diterbitkan: 26/08/2021; Dipublikasikan online: 24/12/2021

\begin{abstract}
Abstrak
Perdagangan intra-industri memainkan peranan penting dalam literatur ekonomi internasional saat ini. Pada tahun 2019, total ekspor Indonesia ke negara-negara anggota RCEP sebesar $61,65 \%$ dari total ekspor Indonesia, dan $44 \%$ dari total ekspor ke RCEP disumbang oleh sektor pertanian. Penelitian ini bertujuan untuk mengkaji tingkat interdependensi Indonesia dengan 14 mitra dagangnya dalam RCEP. Data yang digunakan adalah data sekunder time series arus perdagangan komoditi pertanian Indonesia dengan negara-negara RCEP di tahun 2010-2019 yang diperoleh dari Trademap. Metode analisis data yang digunakan adalah intraindustry trade index. Hasil kajian pola perdagangan Indonesia dan RCEP yang diidentifikasi melalui keterkaitan perdagangan (IIT) menunjukkan komoditas yang memiliki nilai rata-rata IIT tertinggi adalah olahan tepung-tepungan (HS 19). Hal ini menunjukkan jika keterkaitan perdagangan Indonesia RCEP untuk produk tepung-tepungan (HS 19) bersifat dua arah (twoway trade). Sedangkan untuk negara, Malaysia adalah negara yang memiliki keterkaitan perdagangan terkuat dengan Indonesia. Nilai rata-rata IIT Indonesia-RCEP sebesar 19,74 menggambarkan keterkaitan banyak produk pertanian Indonesia dan RCEP yang masih rendah dan tergolong inter-industry trade. Rendahnya nilai IIT ini bisa saja disebabkan masih besarnya perdagangan satu arah di RCEP, dimana Indonesia masih dominan melakukan impor. Oleh karena itu, penting bagi pemerintah untuk lebih meningkatkan ekspor komoditas potensial dengan memberi insentif kepada industri pengolahan produk pertanian melalui keringanan pajak dalam jangka waktu tertentu.
\end{abstract}

Kata kunci: Intra-industry Trade, RCEP, Sektor Pertanian

\begin{abstract}
Intra-industrial trade plays an important role in today's international economic literature. In 2019, Indonesia's total exports to RCEP member countries amounted to $61.65 \%$ of Indonesia's total exports, and $44 \%$ of total exports to RCEP were contributed by the agricultural sector. This study aims to examine the level of interdependence between Indonesia and its 14 trading partners in RCEP. The data used is secondary data from the time series of trade flows of agricultural commodities between Indonesia and RCEP countries in 2010-2019 which were obtained from Trademap. The data analysis method used is the intraindustry trade index. The results of the study show, if there is a tendency to increase the IIT index of Indonesia with trading partners, it's just that when viewed from each RCEP member, the IIT value still tends to fluctuate. Malaysia is an RCEP member country with the highest IIT score in its agricultural sector, on the other hand, the agricultural sector in Cambodia has the
\end{abstract}

https://doi.org/10.30908/bilp.v15i2.570

Published by Trade Analysis and Development Agencies, Ministry of Trade. This is an open access article under the CC BY-NC-SA 4.0 license (http://creativecommons.org/licenses/by-nc-sa/4.0/) 
lowest IIT score. Cereal and flour processed commodities (HS 19) were the commodities with the highest IIT, while meat and edible meat scraps (HS 02) were the commodities with the lowest value. Based on the results of the IIT value, it can be seen that many agricultural products are still classified as inter-industry trade. Therefore, it is important for the government to further increase potential commodity exports by providing incentives to processing agricultural industries through tax breaks for a certain period of time.

Keywords: Intra-industry Trade, RCEP, Agricultural Sector

JEL Classification: F10, F13, F1

\section{PENDAHULUAN}

Regional Comprehensive Economic Partnership (RCEP) adalah hasil dari negosiasi ASEAN Summit 2011 dan lahir pada tahun 2013, namun kesepakatan negosiasi RCEP baru di tandatangani pada November tahun 2020. Ada 15 negara yang berpartisipasi dalam negosiasi RCEP, yaitu ASEAN, RRC, Jepang, Korea, Australia dan Selandia Baru. (Kemendag, 2019). RCEP adalah perjanjian regional terbesar dunia yaitu dengan pangsa pasar $48 \%$ penduduk dunia, $32 \%$ PDB dunia, $27 \%$ perdagangan dunia dan $22 \%$ dari arus investasi dunia (FDI). Hal lain yang mendorong negosiasi masih tetap dilanjutkan meski hanya 15 negara (awalnya India direncanakan ikut bergabung dalam RCEP) yang berpartisipasi adalah karena pertama, negosiasi RCEP memberi semangat positif ditengah ketidakpastian sistem perdagangan pasca perang dagang ASCina. Kedua, adanya sinyal positif berupa kepemimpinan dan komitmen bersama untuk iklim perdagangan dan investasi terbuka di kawasan RCEP (Indonesia.go.id, 2019).

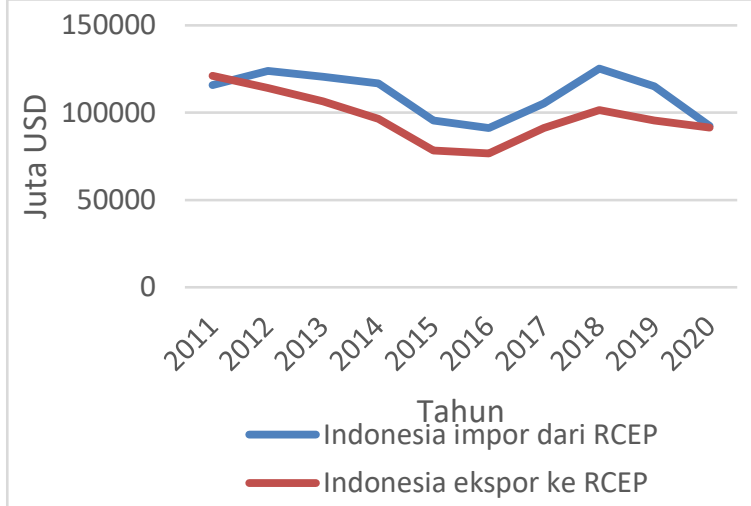

\section{Gambar 1. Kegiatan Ekspor-Impor Indonesia dan RCEP, 2011-2020}

Sumber: Trademap (2020)

Gambaran keseimbangan pasar ekspor impor Indonesia tergambar pada Gambar 1 dimana terlihat perdagangan Indonesia di pasar RCEP mengalami defisit di 10 tahun terakhir. Namun, penting untuk menekankan bahwa kondisi defisit itu tidak selalu buruk, defisit ini bisa menjadi hal yang positif apabila dana ini digunakan untuk tujuantujuan produktif (dimanfaatkan sebagai bahan baku industri). Tetapi kalau defisit 
ini hanya digunakan untuk konsumsi, maka akan terjadi ketidakseimbangan karena defisit tidak menghasilkan tambahan pendapatan di masa mendatang (Nguyen et al., 2020); (Hoang, 2019); (Bojnec \& Ferto, 2016) dan (Ferto, 2015).

Indonesia diperkirakan akan mendapat lebih banyak manfaat dengan keikutsertaannya dalam negosiasi RCEP. Hal ini terlihat dari pertumbuhan ekspor Indonesia sebesar 1,23\% ke negara-negara anggota RCEP dalam lima tahun terakhir. Kontribusi ekspor ke negara-negara RCEP adalah sebesar $57,10 \%$ dari keseluruhan ekspor Indonesia (Trademap, 2020).

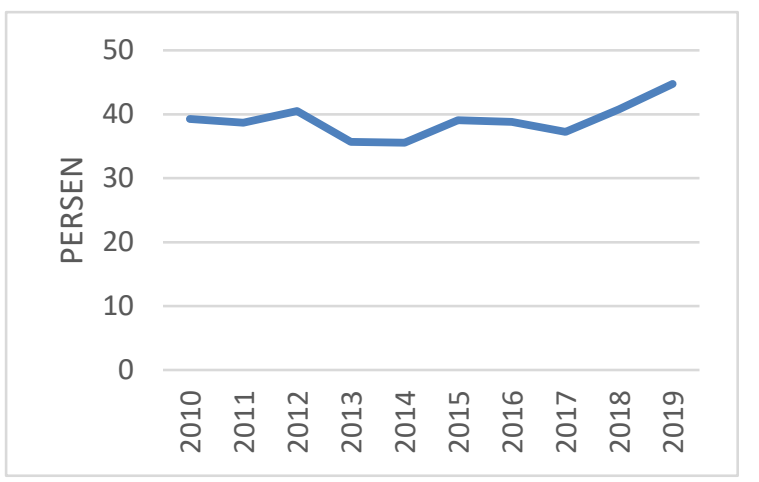

Gambar 2. Kontribusi Sektor Pertanian pada Ekspor Indonesia ke Negara-negara RCEP, 20102019

Sumber: Trademap (2020)

Salah satu sektor yang perlu diperhatikan adalah sektor pertanian, pasalnya kontribusi ekspor Indonesia ke negara-negara RCEP dalam sepuluh tahun terakhir banyak disumbang oleh sektor pertanian (Gambar 2). Sektor pertanian menyumbang ekspor ke negara-negara RCEP rata-rata sebesar $39 \%$ dengan kontribusi terbesar hingga 44\% pada tahun 2019 (Trademap, 2020).

Meski ekspor sektor pertanian berkontribusi besar dalam total ekspor Indonesia ke negara-negara RCEP, dengan jumlah penduduk terbesar kedua setelah Cina, hal ini dapat memperbesar potensi Indonesia untuk defisit perdagangan khususnya di bidang pertanian (Dwipayana \& Kesumajaya, 2014) dan (Lipsey, 1995). Jika Indonesia tidak mengkaji komoditikomoditi strategis yang dimiliki Indonesia, RCEP bisa saja menyebabkan serbuan impor terutama produk pertanian. Lain halnya, jika Indonesia sudah mengkaji produkproduk strategis melalui kajian economic of scale dan diferensiasi produk, serbuan berbagai macam produk pertanian yang sejenis akan bisa lebih dikendalikan. Hal ini terjadi karena pola perdagangan saat ini yang telah berubah dari "banyak varietas, harga rendah dan kuantitas yang kecil" ke "sedikit varietas, harga yang lebih mahal dan kuantitas yang besar". Skala ekonomi menjadi salah satu hal yang 
menjadi perhatian bagi banyak negara (Sun \& Li, 2018); (Li, 2017) dan (Yu \& Qi, 2015).

Dengan pengkategorian produk pertanian strategis, Indonesia diharapkan akan mampu bersaing di pasar RCEP (Nguyen et al., 2020); (Plummer, 2010); (Retnosari, 2018); (Sun \& Li, 2018), dimana itu berarti akan meningkatkan penerimaan devisa negara dan peningkatan beberapa indikator makro ekonomi seperti Produk Domestik Bruto (PDB) dan kesempatan kerja. BPS (2020b) mencatat dari sisi PDB, sektor pertanian memberikan kontribusi sebesar 12,72\% (Rp. 2.013,6 triliun). Nilai kontribusi sektor pertanian memang secara persentase kontribusi cenderung menurun, namun secara nilai, tetap terjadi pertumbuhan PDB pertanian pada tahun 2019 sebesar $3,6 \%$ dari tahun 2018. Apabila dilihat dari sisi penciptaan tenaga kerja, sektor pertanian berdasarkan data Kementan (2020) menjadi penyerap tenaga kerja terbesar di Indonesia yaitu sebesar 29\% dengan jumlah tenaga kerja pertanian sebanyak 38,046 juta orang dari 131,023 juta angkatan kerja Indonesia.

Sektor pertanian juga berkontribusi sebagai satu-satunya sektor penyelamat PDB di tengah krisis
1997-1998 dengan pertumbuhan positifnya. Begitu juga setelah Indonesia dinyatakan resmi resesi di triwulan ke III 2020, sektor pertanian justru mengalami peningkatan sebesar $2,15 \%$, BPS (2020a). Sebagai sektor strategis dalam perekonomian Indonesia, fluktuasi ekspor produk sektor pertanian akan sangat berpengaruh terhadap kesempatan kerja, pengurangan jumlah penduduk miskin, kondisi taraf hidup masyarakat yang tercermin dalam pendapatan perkapita, termasuk perolehan devisa negara. Indonesia yang saat ini ditunjuk sebagai ketua Komite Perundingan Perdagangan RCEP dan ASEAN seharusnya dapat bersemangat memanfaatkan peluang kerja sama ini untuk lebih meningkatkan peluang peningkatan pangsa pasar. Memanfaatkan perundingan RCEP ini salah satunya bisa dimulai dari sektor pertanian yang terus dibangun dan dikembangkan agar dapat memberikan kontribusi positif terhadap perekonomian Indonesia.

Makin terbukanya perdagangan regional merupakan suatu upaya untuk meningkatkan pertumbuhan ekonomi melalui peningkatan volume perdagangan, efisiensi produksi, daya saing industri dalam negeri, mempercepat pertumbuhan output 
serta meningkatkan mobilitas faktor produksi. Perjanjian kerja sama RCEP akan membuka hubungan dagang yang lebih luas dan Indonesia dapat meminimalkan biaya produksi. Namun demikian, kerja sama RCEP dapat menyebabkan peningkatan impor dan kehilangan peluang investasi dan impor, pasalnya seluruh anggota RCEP juga akan bersaing untuk mendapatkan investasi dan ekspor dalam negosiasi RCEP ini.

Berdasarkan latar belakang tersebut, maka penting bagi Indonesia untuk menganalisis komoditi dan negara prioritas agar peluang RCEP ini bisa semaksimal mungkin dimanfaatkan oleh Indonesia. Indonesia harus memiliki strategi untuk menggagas sektor mana yang relatif efisien. Sektor-sektor yang efisien kemungkinan besar memiliki potensi ekspor. Sektor-sektor yang relatif tidak efisien kemungkinan besar justru akan mengalami peningkatan impor.

Teori klasik perdagangan internasional menyatakan jika negara harus fokus untuk memproduksi barang yang mereka miliki keunggulan komparatif. Namun, komoditas yang diperdagangkan secara teori harus berasal dari industri yang berbeda seperti beras dan tekstil. Dalam beberapa dekade terakhir, dengan adanya integrasi negara ke dalam ekonomi global, perdagangan luar negeri antar negara menjadi lebih kompleks dan sulit menjelaskan dengan teori perdagangan klasik. Tren impor dan ekspor produk secara bersamaan dalam waktu yang sama berlangsung sangat cepat.

Istilah "perdagangan intra industri" menjadi salah satu istilah penting dalam industri teori perdagangan baru yang menjelaskan sebagian besar tren saat ini di perdagangan internasional (Nguyen et al., 2020). Perdagangan intra industri itu sendiri adalah perdagangan dalam industri yang sama (Kemendag, 2010) dan (Retnosari, 2018). Perdagangan intra industri mencoba untuk memastikan berapa banyak perdagangan antara dua ekonomi terjadi dalam industri yang sama. Ini didasarkan pada premis bahwa skala ekonomi memberikan insentif untuk berdagang, bahkan ketika faktor endowmen dan preferensi konsumen identik antara mitra ekonomi (CEI, 2009).

Telah banyak penelitian tentang perdagangan intra industri negaranegara di dunia (Retnosari, 2018); (Zhang \& Clark, 2009); (Alhayat, 2012b); (Mikic \& Gilbert, 2009). Secara 
umum, studi ini bisa dikategorikan menjadi dua kelompok. Fokus kelompok pertama menjelaskan alasan adanya perdagangan intra industri (Krugman, 1979) sedangkan kelompok kedua memperhatikan pengukuran sejauh mana IIT (Grubel \& Llyod, 1971). Meski sudah ada banyak jumlah penelitian empiris berkontribusi pada IIT, mulai dari determinan maupun nilai IIT dari negara-negara itu sendiri, kebanyakan hanya memperhatikan negara maju di mana arus perdagangan terjadi karena struktur permintaan dan teknologi produksi yang serupa (Łapińska, 2016).

Hingga saat ini, belum ada studi tentang perdagangan intra industri antara Indonesia dengan negaranegara dalam negosiasi RCEP yang belum lama ini ditandatangani sebagai sebuah perjanjian perdagangan di akhir 2020. Maka penting untuk dianalisis apakah produk Indonesia memiliki keterkaitan perdagangan (intra-industry trade) dengan negara-negara RCEP, sehingga komoditi dan negara-negara yang potensial untuk ekspor Indonesia dapat diidentifikasi. Lebih jauh lagi, harapannya perdagangan antara Indonesia dan mitra dagangnya dapat tumbuh lebih cepat dengan pengenalan perdagangan bebas di negosiasi RCEP ini, studi tentang IIT Indonesia-RCEP ini sangat mendesak dan perlu. Penelitian ini diharapkan dapat memberikan kontribusi sebagai salah satu acuan pemilihan komoditi dan negara potensial di RCEP berdasarkan standar nilai IIT.

Beberapa literatur (Nguyen et al., 2020), (Hoang, 2018), (Bato, 2014), Retnosari (2018) melihat adanya keterkaitan bisa digunakan sebagai alat ukur kinerja ekspor oleh suatu negara sekaligus kegiatan impor dari komoditas yang sama dari negara lain. Ketika adanya keterkaitan, hal ini akan mendekatkan ketergantungan relasi perdagangan antara Indonesia dan negara-negara RCEP. Lebih jauh lagi, negara-negara anggota RCEP yang memiliki interdependensi yang tinggi dengan Indonesia, dapat membantu Indonesia dalam rangka identifikasi diversifikasi pasar dan produk. Masih sedikitnya penelitian tentang hubungan dagang Indonesia dan negara-negara anggota RCEP, studi ini diharapkan dapat menambah referensi bagi pemerintah dalam mengambil kebijakan terkait ekspor, terutama dalam pengembangan ekspor dari sisi perdagangan intra-industri.

\section{METODE}

Untuk menggambarkan interdependensi perdagangan kedua negara dilakukan analisis Intra-Industry Trade 
(IIT). IIT digunakan untuk menganalisis tingkat integrasi dalam suatu kawasan tertentu. Integrasi yang tinggi menunjukkan kedekatan perdagangan di antara negara-negara di kawasan tersebut.

Menurut Kemendag (2010) IIT berawal dari teori keunggulan komperatif, dimana negara yang memiliki keunggulan komperatif pada komoditas tertentu mengekspor komoditas tersebut dan begitu pula sebaliknya, negara tersebut akan mengimpor komoditas yang bukan merupakan keunggulan negaranya. Dasar dalam kegiatan IIT ini adalah pada diferensiasi produk dan economic of scale. Kondisi persaingan internasional memaksa perusahaan untuk berkonsentrasi dengan menghasilkan beberapa jenis produk saja dengan kualitas dan harga terbaik dari produk lainnya. Teori perdagangan baru-baru ini bisa menekan biaya produksi, di sisi lain kebutuhan konsumen pada produk lain dapat dipenuhi melalui impor. IIT yang umum digunakan adalah Grubel-Lloyd Index (GLI) dengan rumus:

$\mathrm{IIT}=\left(\frac{\sum_{\mathrm{i}=1}^{\mathrm{n}}(\mathrm{Xi}+\mathrm{Mi})-\sum_{\mathrm{i}=1}^{\mathrm{n}}|\mathrm{Xi}-\mathrm{Mi}|}{\sum_{\mathrm{i}=1}^{\mathrm{n}}(\mathrm{Xi}+\mathrm{Mi})}\right) \times 100$ dengan I adalah industri ke-I; X adalah ekspor; dan $\mathrm{M}$ adalah impor, atau disederhanakan menjadi:

$\operatorname{IITC}=\left(1-\frac{|X c-M c|}{X c+M c}\right) \times 100$

Dimana $X=$ ekspor komoditas $\mathrm{C}$ Indonesia ke RCEP; dan $\mathrm{M}=$ impor komoditas c Indonesia dari RCEP.

Rasio GLI adalah 0 hingga 100. Jika nilai mendekati 0 , menunjukkan perdagangan bersifat inter-industry yang artinya kegiatan perdagangan hanya melibatkan satu pihak saja (ekspor atau impor saja). Jika indeksnya mendekati 100, menunjukkan perdagangan bersifat intra-industry yang artinya jumlah yang diekspor hampir sama dengan jumlah yang diimpor untuk suatu produk. Sedangkan menurut Austria (2004) klasifikasi dari nilai IIT adalah sebagai berikut.

Tabel 1. Klasifikasi Nilai IIT

\begin{tabular}{cl}
\hline \multicolumn{1}{c}{ IIT } & \multicolumn{1}{c}{ Klasifikasi } \\
\hline 0,00 & $\begin{array}{l}\text { Tidak ada integrasi } \\
\text { (perdagangan satu arah) }\end{array}$ \\
$>0,00-24,99$ & Integrasi Lemah \\
$25,00-49,99$ & Integrasi sedang \\
$50,00-74,99$ & Integrasi kuat \\
$75,00-99,99$ & Integrasi sangat kuat \\
\hline Sumber: Austria (2004)
\end{tabular}

Perdagangan intra-industri sering terjadi antara negara maju karena mereka memiliki tingkat perkembangan dan ukuran pasar yang sama (Nguyen et al., 2020). Indonesia adalah negara 
berkembang, meski telah berada di proses industrialisasi namun hanya memiliki keunggulan komparatif dalam produk padat karya dan teknologi rendah sehingga sektor non migas masih merupakan sektor potensial bagi perdagangan Indonesia (Hotsawadi \& Widyastutik, 2020), khususnya adalah sektor pertanian (Parmadi et al., 2018).

Data perdagangan yang akan diteliti menggunakan kodefikasi Harmonized System (HS). HS adalah sistem kode komoditi ekspor impor yang digunakan sebagai metode pengklasifikasian produk yang diterima secara internasional (Herjanto \& Purwanto, 2010). Penggunaan data perdagangan yang akan diteliti adalah seluruh nilai perdagangan ekspor impor komoditi dengan kode HS 4 digit dari HS 01-24 mulai tahun 2010-2019 di 14 negara anggota RCEP yang bekerja sama dengan Indonesia.

\section{HASIL DAN PEMBAHASAN}

\section{Intra-industry Trade antara Indonesia} dan Negara-Negara Anggota RCEP

Selama beberapa dekade terakhir, perdagangan intra-industri telah menjadi fenomena yang meluas dengan adanya peningkatan penelitian untuk membahas teori dasar untuk masalah ini (Brülhart, 2008). Konsep intraindustri perdagangan dapat didefinisikan sebagai ekspor dan impor secara bersamaan, yaitu produk yang termasuk dalam kategori komoditas yang serupa (Bojnec \& Ferto, 2016), sehingga kesamaan faktor endowmen dan preferensi konsumen antara mitra ekonomi seharusnya tidak menjadi masalah.

Perdagangan intra industri menjadi penting ketika tarif dan non tarif barrier dihapuskan pada arus perdagangan antarnegara ketika adanya perjanjian perdagangan dan adanya perdagangan intra industri akan memperoleh keuntungan dari adanya economic of scale. Dalam hal ini persaingan internasional memaksa setiap perusahaan untuk membatasi model atau tipe produknya agar dapat berkonsentrasi memanfaatkan sumber dayanya untuk menekan biaya produksi per unit sehingga dapat menghasilkan beberapa jenis produk saja tentunya dengan kualitas terbaik dan harga dapat bersaing dari produk lainnya. Disisi lain kebutuhan konsumen akan produk atau tipe lain dipenuhi melalui impor dari negara lain. Disisi lain kebutuhan konsumen akan produk atau tipe lain dipenuhi melalui impor dari negara lain. Melalui teori perdagangan baru ini digambarkan bagaimana kegiatan impor itu tidak selalu memberi dampak 
buruk bagi para pengusaha dalam negeri, namun jika dilakukan dengan strategi perdagangan intra industri, kegiatan ekspor dibarengi impor pada produk tertentu dapat meningkatkan economic of scale dan produk yang terdiferensiasi bagi Indonesia

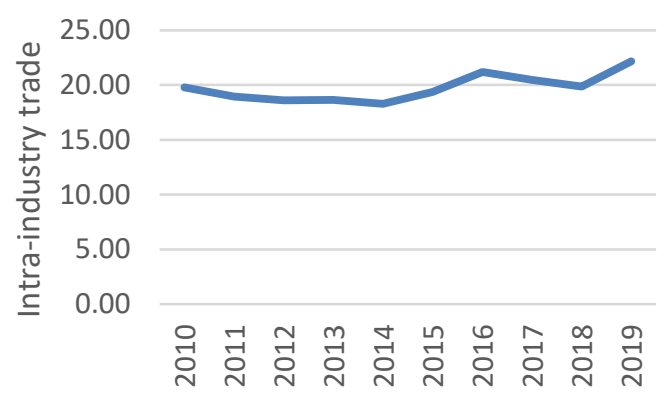

Gambar 3. Nilai Rata-rata Intra-Industry Trade Produk Pertanian antara Indonesia dan Negara RCEP, 2010-2019

Sumber: Trademap (2020), diolah

Tingkat integrasi di masing-masing produk pertanian diukur melalui indeks intra industry trade (IIT). Besarnya IIT menunjukkan besarnya perdagangan intra industri, yaitu besarnya ekspor impor pada komoditi yang sama. Dengan demikian, untuk melihat tingkat integrasi pada produk pertanian pada anggota RCEP dilakukan pengukuran menggunakan indeks IIT.

Selama periode 2010-2019 berdasarkan hasil rata-rata perhitungan IIT produk pertanian antara Indonesia dan negara-negara RCEP untuk komoditas pertanian adalah sebesar
19,74 dan memperlihatkan adanya kecenderungan IIT yang meningkat dalam beberapa tahun terakhir. Gambar 3 menunjukkan meski jika terjadi tren peningkatan nilai IIT, namun nilai integrasi tersebut cenderung naik turun. Selandia Baru, Vietnam, Thailand, Myanmar, Jepang dan Kamboja menunjukkan adanya kecenderungan peningkatan indeks IIT. Sedangan tren penurunan nilai IIT terjadi pada Malaysia, Singapura dan Filipina.

Rata-rata nilai IIT Indonesia-RCEP sebesar 19,74 jika dibandingkan berdasarkan klasifikasi Grubel \& Llyod (1971), nilai IIT Indonesia-RCEP ini tergolong memiliki integrasi yang rendah. Nilai 19,74 adalah hasil ratarata sektor pertanian HS 2 digit yang berasal dari 14 negara RCEP selama tahun 2010 hingga 2019.

\section{Intra-industry Trade masing-masing} Anggota RCEP 2 Digit

Pada Tabel 2 terlihat delapan dari 24 kelompok komoditas memiliki nilai IIT kurang dari $50 \%$ di seluruh negara RCEP. Negara-negara maju biasanya memiliki tingkat IIT yang lebih tinggi daripada negara-negara berkembang, seperti Jepang, Korea Selatan, dan Singapura, memang memiliki IIT yang lebih tinggi daripada negara-negara berpenghasilan rendah (Sawyer et al., 
2010). Terbukti Singapura sebagai negara dengan pelabuhan paling efisien di dunia (Madiah \& Widyastutik, 2020), terlihat memiliki nilai IIT tertinggi diantara anggota RCEP lainnya.

Jepang memiliki beberapa kelompok komoditas dengan nilai integrasi yang kuat hingga sangat kuat, hasil ini didukung oleh hasil analisis Afriandini \& Hastiadi (2018) tentang perdagangan Indonesia dan Jepang yang menunjukkan jika perdagangan
Indonesia dan Jepang saat ini tengah beralih ke arah intra-industri dibandingkan inter-industri.

Berbeda dengan Brunei Darussalam, Kamboja, Laos, dan Myanmar adalah anggota RCEP yang memiliki keterkaitan dagang produk pertanian yang rendah dengan Indonesia. Hal ini sesuai dengan penelitian Sawyer et al. (2010) jika negara berpenghasilan rendah memiliki IIT yang rendah juga.

Tabel 2. Hasil Nilai IIT HS 2 Digit

\begin{tabular}{|c|c|c|c|c|c|c|c|c|c|c|c|c|c|c|}
\hline HS & BRN & KHM & LAO & MLS & MMR & PHL & SGP & THA & VNM & $\mathrm{CHN}$ & JPN & KOR & AUS & NZL \\
\hline 01 & 0.00 & 0.00 & 0.00 & 61.40 & 0.00 & 12.20 & 0.07 & 19.40 & 23.21 & 15.92 & 23.97 & 8.45 & 0.00 & 0.00 \\
\hline 02 & 0.00 & 0.00 & 0.00 & 6.51 & 0.00 & 0.00 & 19.02 & 8.00 & 0.00 & 0.00 & 33.15 & 0.00 & 0.00 & 0.00 \\
\hline 03 & 8.68 & 0.00 & 0.00 & 17.78 & 8.40 & 34.88 & 2.11 & 9.28 & 10.29 & 47.20 & 6.35 & 5.22 & 26.96 & 64.46 \\
\hline 04 & 0.00 & 0.00 & 0.00 & 50.53 & 0.00 & 15.78 & 19.80 & 63.61 & 12.32 & 20.62 & 57.42 & 9.95 & 0.83 & 0.15 \\
\hline 05 & 0.00 & 0.00 & 0.00 & 25.29 & 0.00 & 7.57 & 32.34 & 32.14 & 32.93 & 43.83 & 23.93 & 30.16 & 2.06 & 1.66 \\
\hline 06 & 0.00 & 0.00 & 0.00 & 14.53 & 1.25 & 0.56 & 4.52 & 30.08 & 28.37 & 56.34 & 3.99 & 0.56 & 4.41 & 19.79 \\
\hline 07 & 0.00 & 0.00 & 0.00 & 67.15 & 0.00 & 26.38 & 9.26 & 46.57 & 30.37 & 8.57 & 0.97 & 44.21 & 2.80 & 3.07 \\
\hline 08 & 0.00 & 0.00 & 0.00 & 11.01 & 16.73 & 49.10 & 1.43 & 42.76 & 41.95 & 17.50 & 43.10 & 68.89 & 20.09 & 23.42 \\
\hline 09 & 0.00 & 2.76 & 9.31 & 28.76 & 23.98 & 0.07 & 6.34 & 25.19 & 63.18 & 50.84 & 2.54 & 2.59 & 3.92 & 0.01 \\
\hline 10 & 0.00 & 0.00 & 0.00 & 31.27 & 0.00 & 19.31 & 53.99 & 0.64 & 2.41 & 0.01 & 38.42 & 17.22 & 0.00 & 0.00 \\
\hline 11 & 0.00 & 0.00 & 0.00 & 45.12 & 0.99 & 11.76 & 38.97 & 2.34 & 25.84 & 15.82 & 94.27 & 73.61 & 7.09 & 9.63 \\
\hline 12 & 0.00 & 0.00 & 0.00 & 37.06 & 3.84 & 4.49 & 34.88 & 76.67 & 16.94 & 46.61 & 79.36 & 33.90 & 73.30 & 0.19 \\
\hline 13 & 0.00 & 0.00 & 0.00 & 28.93 & 0.00 & 58.06 & 73.93 & 27.60 & 0.32 & 41.26 & 39.54 & 64.99 & 13.28 & 25.77 \\
\hline 14 & 0.00 & 0.00 & 0.00 & 2.06 & 0.00 & 0.00 & 0.73 & 0.54 & 25.69 & 21.45 & 0.93 & 0.00 & 1.98 & 0.00 \\
\hline 15 & 0.00 & 0.00 & 0.00 & 12.21 & 0.00 & 1.69 & 8.71 & 20.94 & 2.38 & 0.60 & 10.05 & 3.11 & 32.54 & 28.64 \\
\hline 16 & 5.64 & 0.00 & 0.00 & 69.36 & 0.00 & 35.17 & 64.82 & 21.53 & 16.87 & 59.93 & 0.72 & 24.41 & 65.03 & 26.45 \\
\hline 17 & 0.00 & 0.00 & 0.00 & 81.18 & 33.70 & 22.24 & 68.89 & 4.02 & 9.47 & 6.50 & 60.01 & 50.13 & 3.16 & 54.88 \\
\hline 18 & 0.00 & 0.00 & 0.00 & 48.90 & 0.00 & 3.80 & 42.08 & 9.73 & 4.48 & 22.69 & 2.32 & 1.85 & 20.53 & 6.10 \\
\hline 19 & 0.01 & 0.05 & 0.00 & 87.39 & 6.21 & 16.66 & 51.85 & 75.88 & 11.95 & 41.42 & 47.81 & 62.72 & 56.96 & 77.44 \\
\hline 20 & 0.00 & 0.20 & 0.00 & 70.99 & 0.00 & 77.96 & 56.61 & 5.69 & 46.08 & 27.40 & 8.81 & 34.00 & 81.10 & 65.98 \\
\hline 21 & 0.00 & 0.00 & 0.00 & 89.23 & 0.00 & 0.79 & 76.61 & 65.91 & 45.19 & 23.17 & 83.79 & 10.86 & 58.04 & 44.99 \\
\hline 22 & 0.00 & 0.00 & 0.00 & 14.38 & 0.00 & 1.05 & 26.61 & 13.49 & 21.05 & 18.17 & 20.43 & 16.16 & 29.14 & 32.68 \\
\hline 23 & 0.00 & 0.00 & 0.00 & 48.34 & 0.00 & 6.62 & 10.40 & 55.86 & 32.03 & 63.37 & 16.09 & 48.74 & 14.00 & 59.07 \\
\hline 24 & 0.00 & 1.54 & 21.83 & 22.75 & 8.73 & 71.58 & 5.96 & 43.97 & 28.89 & 4.01 & 7.83 & 46.61 & 5.84 & 0.11 \\
\hline
\end{tabular}

Sumber: Trademap (2020), diolah

Ket: 123 : Nilai IIT HS 2 Digit tertinggi diantara anggota RCEP (highlight kuning)

123 : Nilai IIT yang bernilai lebih dari 50 9highlight tulisan merah) 
Berdasarkan hasil perhitungan masing-masing klasifikasi komoditi dengan kode HS 2 digit, menunjukkan kinerja trade flow antara Indonesia dan anggota RCEP lainnya lebih besar terjadi pada produk olahan tepung (HS 19), olahan sayur, buah, kacangkacangan atau bagian tanaman lainnya (HS 20), dan bermacam-macam makanan lain (HS 21). Besarnya nilai IIT ini terjadi karena semakin meningkatnya integrasi ekonomi, yang menyebabkan penurunan tarif. Hal ini berdampak positif pada ekspor beberapa produk pertanian di dunia, khususnya di beberapa negara anggota RCEP (Kemendag, 2016); (Ningsih \& Kurniawan, 2016); dan (Kemenperin, 2020).

Sebaliknya, daging dan sisa daging yang bisa dimakan (HS 02), bahan anyaman nabati (HS 14), lemak dan minyak nabati (HS 15) adalah klasifikasi komoditi dengan nilai integrasi terkecil diantara produk Indonesia dan negara-negara anggota RCEP. Jiuhardi (2016) menyatakan memang Indonesia masih belum mampu memenuhi kebutuhan daging sapi dalam negeri, sehingga masih tergantung dengan impor karena produk lokal hanya mampu menyediakan $73,98 \%$ dari kebutuhan Indonesia dan 26,02\% itu diperoleh dari impor. Amalina et al., (2018) juga mendapati jika HS 14 Indonesia memiliki nilai IIT yang rendah. Kode HS 15 memang secara rata-rata memiliki rata-rata IIT yang rendah karena memang tidak seluruh negara RCEP yang melakukan perdagangan intra industri untuk komoditi HS 15. Beberapa negara RCEP yang melakukan perdagangan intra industri HS 15 adalah Jepang (Kemenperin, 2020), Selandia Baru dan Australia (Nuryanti, 2010).

\section{Klasifikasi Nilai Intra-Industry Trade masing-masing Anggota RCEP 4 Digit \\ Total 196 produk pertanian dari} data trade flow HS 01-24 yang berasal masing-masing negara anggota RCEP, terlihat ketimpangan nilai IIT produk pertanian yang diperdagangkan masingmasing RCEP negara (Tabel 3). Pada Tabel 3 terlihat berapa jumlah produk yang saling memiliki integrasi, ada negara yang memiliki banyak produk dengan nilai IIT tinggi dan adapula negara yang tidak memiliki keterkaitan dengan produk pertanian Indonesia berdasarkan nilai IIT. 
Tabel 3. Intra-Industry Trade Indonesia ke RCEP, 2010-2019

\begin{tabular}{lccccc}
\hline \multirow{2}{*}{ Negara } & \multicolumn{5}{c}{ Intra-Industry Trade } \\
\cline { 2 - 6 } & Tidak ada & Lemah & Sedang & Kuat & $\begin{array}{c}\text { Sangat } \\
\text { Kuat }\end{array}$ \\
\hline Brunei Darussalam & 193 & 3 & 0 & 0 & 0 \\
Kamboja & 193 & 2 & 1 & 0 & 0 \\
Laos & 193 & 3 & 0 & 0 & 0 \\
Malaysia & 63 & 90 & 25 & 15 & 3 \\
Myanmar & 159 & 7 & 0 & 0 & 0 \\
Filipina & 141 & 45 & 8 & 2 & 0 \\
Singapura & 53 & 110 & 23 & 8 & 2 \\
Tailand & 100 & 74 & 17 & 4 & 1 \\
Vietnam & 111 & 68 & 14 & 3 & 0 \\
RRC & 77 & 93 & 15 & 9 & 2 \\
Jepang & 80 & 86 & 16 & 12 & 2 \\
Korea & 99 & 74 & 16 & 6 & 1 \\
Australia & 78 & 93 & 16 & 9 & 0 \\
Selandia Baru & 151 & 36 & 9 & 0 & 0 \\
Sumber: Trademap (2020), diolah & & & & &
\end{tabular}

Tabel 3 menggambarkan jumlah komoditi berdasarkan tingkatan klasifikasi nilai IIT. Klasifikasi terbagi dari tidak ada perdagangan intra industri hingga intra industri sangat kuat. Tidak ada intra-industry trade artinya adalah hanya terjadi perdagangan satu arah (inter-industry trade) atau tidak adanya interdependensi. IIT sangat kuat menggambarkan jika kedua negara partner memiliki ketergantungan perdagangan yang besar.

Berdasarkan hasil perhitungan IIT untuk negara-negara anggota RCEP, memperlihatkan jika Singapura menjadi partner dagang sebagai negara tujuan ekspor produk pertanian yang memiliki interdependensi dengan produk pertanian Indonesia terbanyak, yaitu 143 dari 196 jenis selama 10 tahun, selanjutnya diikuti oleh Malaysia sebanyak 133 jenis. Sebaliknya, Brunei Darussalam, Kamboja dan Laos menjadi anggota RCEP yang memiliki produk dengan integrasi inter industri (one way) terbanyak.

Sementara itu, berdasarkan hasil perhitungan indeks GL untuk masingmasing mitra dagang, bukan hanya terlihat klasifikasi berapa produk yang memiliki integrasi intra industri, tetapi juga dapat diketahui bagaimana pola perdagangan intra industri antara Indonesia dengan negara-negara tersebut. Level IIT dari masing-masing anggota RCEP. 
Nilai IIT Komoditi Unggulan masingmasing Anggota RCEP

Sebagaimana penjelasan diatas, jika tidak semua negara anggota RCEP melakukan perdangan dua arah dengan Indonesia secara konsisten untuk produk pertanian. Dapat dilihat pada hasil perhitungan indeks IIT pada Tabel 4 hingga Tabel 17.

\section{Brunei Darussalam}

Brunei Darussalam hanya memiliki tiga produk yang memiliki integrasi perdagangan dua arah dengan Indonesia. Namun, dari ketiga produk tersebut tidak ada satupun yang memiliki nilai IIT yang tinggi.

Tabel 4. IIT Indonesia dan Brunei

\section{Darussalam}

\begin{tabular}{ccc}
\hline No & Kode HS & $\begin{array}{c}\text { Dari Indonesia ke } \\
\text { Brunei Darussalam }\end{array}$ \\
\hline 1 & 0303 & 2.56 \\
\hline
\end{tabular}

Sumber: Trademap (2020), diolah

Nilai IIT Indonesia Brunei Darussalam sangat rendah, nilai ratarata IIT nya hanya 0,0175 selama 10 tahun terakhir. Ikan beku tidak termasuk fillet (HS 0303) adalah satu-satunya produk pertanian yang memiliki integrasi intra industri Indonesia dan Brunei Darussalam.

Meski memiliki riwayat perdagangan intra industri yang rendah, namun Brunei Darussalam memiliki potensi besar sebagai pasar ekspor Indonesia (Ambarita \& Sirait, 2019).

\section{Kamboja}

Nilai IIT Indonesia Kamboja juga masih tergolong rendah, nilai rata-rata IIT nya hanya 0,19 selama 10 tahun terakhir. Menurut Hermawan (2017) secara umum ekspor komoditas pertanian tumbuh lebih besar dari impor Indonesia, hanya saja memang masih bersifat perdagangan inter industri.

Tabel 5. IIT Indonesia dan Kamboja

\begin{tabular}{ccc}
\hline No & Kode HS & $\begin{array}{c}\text { Dari Indonesia ke } \\
\text { Kamboja }\end{array}$ \\
\hline 1 & 2401 & 37.27 \\
2 & 1905 & 0.10 \\
\hline \multicolumn{2}{l}{ Sumber: } & Trademap (2020), diolah
\end{tabular}

Sampah tembakau (HS 2401) adalah satu-satunya produk pertanian yang memiliki integrasi intra industri Indonesia dan Kamboja. Hal ini adalah hal yang wajar karena memang Kamboja 15 tahun terkahir fokus pada ekspor tekstil dan garmen yang merupakan katalisator utama peningkat ekspor mereka (Amir et al., 2020)

\section{Laos}

Nilai IIT Indonesia Laos sangat rendah, nilai rata-rata IIT nya hanya 0,098 selama 10 tahun terakhir. Nizar and Wibowo (2007) menyampaikan IIT ekspor produk pertanian Indonesia ke Laos 2005 adalah 38,30 jauh lebih 
besar dari non pertanian dengan nilai IIT yang tidak sampai $1 \%$.

Tabel 6. IIT Indonesia dan Laos

\begin{tabular}{ccc}
\hline No & Kode HS & $\begin{array}{c}\text { Dari Indonesia } \\
\text { ke Laos }\end{array}$ \\
\hline 1 & 0901 & 9.24 \\
2 & 2403 & 9.00 \\
3 & 2402 & 0.98 \\
\hline
\end{tabular}

Sumber: Trademap (2020), diolah

Sama seperti Kamboja, secara umum ekspor Indonesia ke Laos untuk komoditas pertanian tumbuh lebih besar dari impor Indonesia, hanya saja memang masih bersifat perdagangan inter industri (Hermawan, 2017).

\section{Malaysia}

Malaysia adalah salah satu negara berkembang yang saat ini sedang berproses ke tahap industrialisasi dan dianggap berhasil melakukan diversifikasi ekspor sumberdaya alamnya yang melimpah (Amir et al., 2020).

Nilai ekspor IIT Indonesia ke Malaysia memiliki nilai yang tidak terlalu mengalami fluktuasi di tahun 1993 hingga 2005, dimana nilai IIT tahun 1993 adalah 0,25 dan 2005 adalah 0,23 (Nizar \& Wibowo, 2007). Tidak terlalu berbeda dengan tahun 1993 hingga 2005, kondisi perdagangan di sepuluh tahun terakhir ini cenderung juga mengalami penurunan, yaitu pada tahun 2010 nilai IIT Indonesia ke Malaysia adalah 16,70 dan menurun menjadi 14,23 di tahun 2019. Senada dengan hasil penelitian Ningsih \& Kurniawan (2016), meski Indonesia masih menempati posisi pertama sebagai eksportir pertanian ke Malaysia, namun dengan intensitas yang terus menurun setiap tahunnya.

\section{Tabel 7. IIT Indonesia dan Malaysia}

\begin{tabular}{ccc}
\hline No & Kode HS & $\begin{array}{c}\text { Dari Indonesia } \\
\text { ke Malaysia }\end{array}$ \\
\hline 1 & 2101 & 82.56 \\
2 & 1905 & 81.03 \\
3 & 2106 & 75.93 \\
4 & 1704 & 74.28 \\
5 & 2008 & 73.23 \\
6 & 2009 & 71.16 \\
7 & 1805 & 66.74 \\
8 & 1604 & 66.44 \\
9 & 0303 & 64.44 \\
10 & 2007 & 59.48 \\
11 & 0810 & 57.59 \\
12 & 1517 & 57.35 \\
13 & 2103 & 56.08 \\
14 & 1806 & 54.08 \\
15 & 2309 & 53.92 \\
16 & 1516 & 52.97 \\
17 & 1202 & 52.50 \\
18 & 1901 & 52.36 \\
\hline
\end{tabular}

Sumber: Trademap (2020), diolah

\section{Filipina}

Rata-rata IIT komoditi pertanian Indonesia dan Filipina tertinggi terjadi pada tahun 2019 yaitu 5,12 dengan rata-rata 3,85 di sepuluh tahun terakhir. Pada Tabel 3 telah disampaikan jika ada 55 komoditi pertanian Indonesia yang tergolong dalam perdagangan intra 
industri, dan 10 diantara 55 tergolong komoditi dengan nilai IIT sedang hingga kuat. Biji, buah, dan spora (HS 1209) menjadi komoditi pertanian Indonesia yang memiliki interdependensi tertinggi dengan Filipina.

Tabel 8. IIT Indonesia dan Filipina

\begin{tabular}{ccc}
\hline No & Kode HS & $\begin{array}{c}\text { Dari Indonesia ke } \\
\text { Filipina }\end{array}$ \\
\hline 1 & 1209 & 71.66 \\
2 & 1901 & 50.36 \\
3 & 2401 & 47.72 \\
4 & 0303 & 46.26 \\
5 & 1302 & 46.12 \\
6 & 1904 & 43.67 \\
7 & 0406 & 42.85 \\
8 & 1702 & 38.40 \\
9 & 0307 & 34.68 \\
10 & 2103 & 26.36 \\
\hline
\end{tabular}

Sumber: Trademap (2020), diolah

Diantara ASEAN-4 dalam Widarjono (2009) Filipina adalah negara dengan nilai IIT terendah, yaitu sebesar 1,29 di tahun 2005, nilai IIT Filipina yang rendah ini juga didukung oleh (Nizar \& Wibowo 2007). Meski Filipina dinilai sebagai salah satu negara yang tidak ramah dalam regulasi perdagangan Internasional (Madiah \& Widyastutik, 2020), Filipina memiliki beberapa komoditi dengan nilai IIT tinggi.

\section{Myanmar}

Secara umum ekspor Indonesia ke Myanmar untuk komoditas pertanian tumbuh lebih besar dari impor Indonesia, hanya saja memang masih bersifat perdagangan inter industry (Hermawan, 2017).

Tabel 9. IIT Indonesia dan Myanmar

\begin{tabular}{ccc}
\hline No & Kode HS & $\begin{array}{c}\text { Dari Indonesia ke } \\
\text { Myanmar }\end{array}$ \\
\hline 1 & 0306 & 4.25 \\
2 & 1902 & 3.83 \\
3 & 2401 & 2.08 \\
4 & 1702 & 1.92 \\
\hline \multicolumn{2}{l}{ Sumber: Trademap (2020), diolah }
\end{tabular}

\section{Singapura}

IIT Indonesia dan Singapura pada komoditi pertanian rutin diadakan setiap tahunnya dengan kecenderungan nilai yang meningkat. Tabel 9 menampilkan 10 dari 196 produk pertanian yang memiliki nilai IIT dengan tingkat keterkaitan kuat hingga sangat kuat dalam 10 tahun terakhir (2010-2019). Nilai rata-rata IIT sektor pertanian mulai 2010-2019 adalah 12,27. Komoditi dengan tingkat keterkaitan intra industri tertinggi adalah tepung terigu.

Widarjono (2009) dan Nizar \& Wibowo (2007) menggambarkan riwayat perdagangan IIT pertanian Indonesia dan Singapura di tahun Indonesia dan Singapura di tahun 1995 sebesar 4,36 hingga naik lebih dari tiga kali di sepuluh tahun kemudian yaitu dengan nilai IIT sebesar 13,48 di tahun 2005. Peningkatan terjadi hingga tahun 2010, namun mulai tahun 2012 ekspor komoditi pertanian Indonesia ke 
Singapura menurun tajam (Ningsih \& Kurniawan, 2016). Meski terjadi penurunan, namun tingkat IIT Indonesia dan Singapura masih tergolong tinggi diantara peserta RCEP, hal ini terjadi karena ekonomi Singapura sangat dipengaruhi oleh perdagangan internasional. Singapura juga didukung dengan terminal perdagangan terbesar di ASEAN dan kedua di dunia (Amir et al., 2020), serta indeks infrastruktur transportasi tertinggi di antara anggota RCEP (Madiah \& Widyastutik, 2020).

Tabel 10. IIT Indonesia dan Singapura

\begin{tabular}{ccc}
\hline No & Kode HS & $\begin{array}{c}\text { Dari Indonesia ke } \\
\text { Singapura }\end{array}$ \\
\hline 1 & 1101 & 84.87 \\
2 & 1005 & 76.97 \\
3 & 2106 & 71.80 \\
4 & 2203 & 71.17 \\
5 & 1604 & 69.21 \\
6 & 1803 & 66.93 \\
7 & 1702 & 58.19 \\
8 & 1904 & 57.87 \\
9 & 1806 & 52.87 \\
10 & 2102 & 52.62 \\
\hline
\end{tabular}

Ketahanan pangan Singapura paling tinggi di dunia, meski $90 \%$ pangan yang dikonsumsinya dipenuhi melalui impor. Singapura menjadi pusat logistik dunia dan dengan food security index kedua di dunia setelah Amerika. Singapura merupakan negara yang mengandalkan konsep perantara perdagangan dengan membeli barang- barang mentah dan mengolahnya untuk diekspor kembali.

\section{Thailand}

Nilai IIT ekspor komoditi pertanian Indonesia ke Thailand pada tahun 1995 sebesar 7,69 (Widarjono, 2009). Ratarata nilai IIT selama 10 tahun terakhir dari 2010 hingga 2019 adalah 7,12 nilai ini tidak jauh berbeda dengan nilai IIT di tahun 1995.

\section{Tabel 11. IIT Indonesia dan Thailand}

\begin{tabular}{ccc}
\hline No & Kode HS & $\begin{array}{c}\text { Dari Indonesia ke } \\
\text { Thailand }\end{array}$ \\
\hline 1 & 1209 & 76.06 \\
2 & 1902 & 61.93 \\
3 & 2105 & 57.48 \\
4 & 2106 & 56.17 \\
5 & 0811 & 55.26 \\
\hline
\end{tabular}

Sumber: Trademap (2020), diolah

Thailand saat ini fokus pada peningkatan nilai tambah sumberdaya alam yang berorientasi ekspor komoditi pertanian dan perikanan (Amir et al., 2021). Total komoditi pertanian yang memiliki integrasi dengan Indonesia berjumlah 96 komoditi. Biji, buah, dan spora (HS 1209) dari Indonesia adalah komoditi pertanian dengan integrasi yang kuat dengan Thailand.

\section{Vietnam}

Vietnam menduduki posisi keempat setelah Thailand di ASEAN berdasarkan nilai IIT. Nilai IIT Thailand dengan Indonesia adalah 5,95 dan jumlah komoditi yang terintegrasi 
dengan Indonesia adalah 96 dari 196 komoditi pertanian. Nilai IIT Thailand mulai tahun 2016 terus mengalami peningkatan setiap tahunnya, hal ini bisa saja terjadi karena Vietnam saat ini tengah membuat master plan kebijakan yang diharapkan dapat melancarkan hubungan dagangnya dengan negara lain. Salah satunya mempromosikan produk yang memiliki nilai tambah tinggi dan mengurangi ekspor bahan mentah (Amir et al., 2020).

Tabel 12. IIT Indonesia dan Vietnam

\begin{tabular}{ccc}
\hline No & Kode HS & $\begin{array}{c}\text { Dari Indonesia ke } \\
\text { Vietnam }\end{array}$ \\
\hline 1 & 0906 & 68.19 \\
2 & 2401 & 58.63 \\
3 & 2101 & 51.68 \\
4 & 0902 & 49.38 \\
5 & 2309 & 45.78 \\
6 & 0901 & 45.43 \\
7 & 0304 & 45.19 \\
8 & 2103 & 44.88 \\
9 & 2009 & 37.54 \\
10 & 1901 & 27.29 \\
11 & 1604 & 25.23 \\
\hline Sumber: Trademap (2020), diolah
\end{tabular}

Hermawan (2017) menyatakan ekspor dan daya saing komoditas pertanian Indonesia terus meningkat setiap tahunnya, namun Ningsih dan Kurniawan (2016) menemukan hasil jika Indonesia belum memanfaatkan pasar regional secara optimal
Cina

Nilai IIT produk pertanian Indonesia dengan Cina memperlihatkan adanya kecenderungan peningkatan dalam 10 tahun terakhir. Tren IIT yang terus meningkat hal yang wajar jika nilai IIT tertinggi terjadi di tahun 2019 yaitu sebesar 12,08 dan rata-rata IIT dalam kurun waktu 10 tahun ini adalah 9,38. Nilai IIT pertanian yang cenderung meningkat justru berbanding terbalik dengan sektor manufaktur yang mengalami penurunan indeks IIT Astriana (2015) dan (Mayadewi \& Purwanti, 2020).

Tabel 13. IIT Indonesia dan Cina

\begin{tabular}{ccc}
\hline No & Kode HS & $\begin{array}{c}\text { Dari Indonesia } \\
\text { ke Cina }\end{array}$ \\
\hline 1 & 1211 & 82.09 \\
2 & 0303 & 77.59 \\
3 & 2101 & 71.36 \\
4 & 0802 & 68.61 \\
5 & 0810 & 64.68 \\
6 & 2008 & 61.93 \\
7 & 0904 & 61.39 \\
8 & 1207 & 57.58 \\
9 & 1904 & 53.64 \\
10 & 0602 & 52.03 \\
11 & 1301 & 50.43 \\
\hline
\end{tabular}

Sumber: Trademap (2020), diolah

Produk dengan tingkat keterkaitan tertinggi Indonesia dengan Cina adalah tanaman biji-bijian dan buah-buahan, dari jenis yang terutama digunakan dalam pembuatan wewangian, obatobatan (HS 1211). Tren IIT yang 
meningkat, sehingga nilai IIT tertinggi terjadi di tahun 2019 yaitu sebesar 12,08 dan rata-rata IIT dalam kurun waktu 10 tahun ini adalah 9,38.

Kode HS 01 hingga 05 merupakan komoditas hewan dan produk hewani memiliki nilai IIT yang tinggi kecuali HS 02, hasil ini didukung oleh Alhayat (2012) yang menyatakan salah satu dari tiga komoditas yang memiliki intraindustri yang kuat antara Indonesia dan Cina adalah hewan dan produk hewani.

Jepang

Jepang memiliki riwayat perdagangan IIT yang berfluktuasi dari nilai 8,88 hingga 11,72 . Nilai rata-rata IIT adalah 10,24 dan nilai IIT di tahun 2019 adalah 9,88. Food preparation nes (HS 2106) adalah produk pertanian Indonesia dengan nilai IIT tertinggi di Jepang.

Negara dengan tingkat penyerapan teknologi sebagai kegiatan ekonomi (Madiah \& Widyastutik, 2020) ini berdasarkan laporan ITPC (2018), menyatakan kelompok HS 210690, edible milkfat dan gula merupakan campuran bahan makanan yang paling banyak diimpor oleh Jepang dari Indonesia dalam kurun lima tahun terakhir. Kedua bahan tersebut memiliki pangsa masing-masing sebesar $11,2 \%$ dan $11,1 \%$. Satriana et al. (2019) juga mendukung jika kopi (HS 9001) adalah satu komoditi prioritas ekspor ke Jepang.

Tabel 14. IIT Indonesia dan Jepang

\begin{tabular}{ccc}
\hline No & Kode HS & $\begin{array}{c}\text { Dari Indonesia } \\
\text { ke Jepang }\end{array}$ \\
\hline 1 & 2106 & 77.01 \\
2 & 1515 & 75.68 \\
3 & 0403 & 73.53 \\
4 & 1806 & 70.53 \\
5 & 2309 & 67.75 \\
6 & 2301 & 61.46 \\
7 & 2209 & 60.88 \\
8 & 1108 & 60.53 \\
9 & 1905 & 56.90 \\
10 & 1902 & 56.77 \\
11 & 0902 & 56.25 \\
12 & 1101 & 56.23 \\
13 & 1704 & 54.50 \\
14 & 2009 & 50.45 \\
\hline
\end{tabular}

Sumber: Trademap (2020), diolah

\section{Korea Selatan}

Nilai IIT Indonesia-Korea Selatan berfluktuasi dengan rata-rata 7,46 dan IIT 2019 adalah 6,30. Olahan berupa ekstrak, esens dan konsentrat dengan bahan dasar dari kopi dan teh (HS 2101) adalah produk pertanian Indonesia dengan nilai IIT tertinggi di Korea Selatan.

Korea Selatan fokus mempersiapkan energi terbarukan untuk keluar dari ketergantungan pada impor migas yang salah satu mitranya adalah Indonesia, dan produk migas adalah salah satu komoditas utama perdagangan Indonesia dengan Korea 
Selatan. Maka dibuatlah skema untuk meningkatkan ekspor pertanian ke Korea Selatan sebagai ganti dari produk migas (Ayu \& Wibisono, 2017).

Tabel 15. IIT Indonesia dan Korsel

\begin{tabular}{ccc}
\hline No & Kode HS & $\begin{array}{c}\text { Dari Indonesia ke } \\
\text { Korea Selatan }\end{array}$ \\
\hline 1 & 2101 & 80.87 \\
2 & 1902 & 74.00 \\
3 & 1504 & 66.19 \\
4 & 2103 & 63.97 \\
5 & 0508 & 58.76 \\
6 & 1702 & 57.38 \\
7 & 2005 & 50.89 \\
\hline
\end{tabular}

\section{Australia}

Nilai IIT berfluktuasi dengan ratarata 8,82 dan IIT 2019 adalah 7,43. Tepung sereal (tidak termasuk gandum atau meslin) adalah komoditi pertanian dengan nilai IIT tertinggi untuk perdagangan Indonesia dan Australia. Australia adalah mitra dagang kesembilan terbesar Indonesia meski memiliki neraca perdagangan yang defisit bagi Indonesia (Andriani \& Andre, 2017). Perdagangan Indonesia dan Australia terindikasi saling bergantung (Susanto, 2019), hal ini sejalan dengan hasil olah nilai IIT Indonesia-Australia yang beberapa komoditinya memiliki indeks IIT yang tinggi.

Kerja sama perdagangan Indonesia dan Australia ini menguntungkan khususnya pada komoditas pertanian seperti ternak hidup dan daging merah, kapas dan gandum. Sebaliknya bagi Australia, Indonesia adalah pasar ekspor gandum terbesar kedua, dan pasar ternak, daging dan kapas terbesar bagi Australia (DPR RI, 2017)

Tabel 16. IIT Indonesia dan Australia

\begin{tabular}{ccc}
\hline No & Kode HS & $\begin{array}{c}\text { Dari Indonesia ke } \\
\text { Australia }\end{array}$ \\
\hline 1 & 1102 & 66.62 \\
2 & 2009 & 66.59 \\
3 & 2106 & 66.25 \\
4 & 0910 & 65.30 \\
5 & 2202 & 63.70 \\
6 & 0813 & 61.67 \\
7 & 0710 & 61.60 \\
8 & 1301 & 61.21 \\
9 & 0303 & 48.33 \\
10 & 2005 & 41.57 \\
11 & 0302 & 32.17 \\
12 & 2309 & 10.80 \\
\hline
\end{tabular}

Sumber: Trademap (2020), diolah

\section{Selandia Baru}

Nilai IIT memperlihatkan adanya kecenderungan peningkatan indeks IIT dengan rata-rata 2,79 dan IIT 2019 adalah 3,48 . Indeks intra industri produk pertanian Indonesia di Selandia Baru tidak terlalu besar, terbukti dengan nilai IIT paling tinggi hanya sebatas integrasi berskala sedang. Moluska yang layak untuk dikonsumsi manusia baik dalam cangkang atau tidak, hidup, segar, dingin, beku, dikeringkan, diasinkan atau dalam air garam (HS 0307) adalah komoditi pertanian Indonesia dengan nilai IIT tertinggi di Selandia Baru. 
Riwayat perdagangan Selandia Baru dan Indonesia mengalami puncak sebelum tahun 2010 (Nuryanti, 2010), namun setelah tahun 2010 mulai terjadi penurunan ekspor Indonesia ke Selandia baru (Hikmah et al., 2018) dan (Sari, 2018). Selandia Baru sebenarnya bukanlah pasar ekspor utama bagi Indonesia, namun dalam beberapa kali kerja sama, isu yang dibahas adalah tentang bidang pertanian (Fajri \& Rani, 2016).

\section{Tabel 17. IIT Indonesia dan Selandia}

\section{Baru}

\begin{tabular}{ccc}
\hline No & Kode HS & $\begin{array}{c}\text { Dari Indonesia ke } \\
\text { Selandia Baru }\end{array}$ \\
\hline 1 & 0307 & 43.87 \\
2 & 2106 & 42.29 \\
3 & 2203 & 40.06 \\
4 & 1504 & 34.79 \\
5 & 0710 & 33.64 \\
6 & 0303 & 31.17 \\
7 & 1702 & 29.19 \\
8 & 1806 & 28.37 \\
9 & 1704 & 28.29 \\
\hline
\end{tabular}

Berdasarkan nilai IIT 10 komoditas unggulan Indonesia ke RCEP dari 2010 hingga 2019, komoditas yang memiliki nilai IIT tertinggi adalah olahan tepungtepungan (HS 19). Hal ini menunjukkan bahwa keterkaitan perdagangan Indonesia dengan RCEP untuk produk olahan tepung-tepungan bersifat dua arah (two-way trade). Indonesia harus menjaga mutu dan kualitas dari produk tepung-tepungan tersebut agar keterkaitan ini dapat berlanjut. Hal ini menunjukkan bahwa keterkaitan perdagangan Indonesia dengan dunia untuk produk tepung-tepungan bersifat dua arah (two-way trade). Indonesia harus menjaga mutu dan kualitas dari produk produk unggulan tersebut agar keterkaitan ini dapat berlanjut. Nilai Nilai IIT komoditas lain yang masuk 10 besar berturut-turut adalah aneka olahan yang dapat dimakan (HS 21), Olahan sayur, buah, kacang, dan bagian tumbuhan (HS 20), Minyak dari biji dan buahbuahan (HS 12), gula (HS 17), Olahan daging dari ikan atau dari krustasea, moluska (HS 16), Getah, resin dan ekstrak nabati lainnya (HS 13), Residu dan limbah dari industri makanan; pakan ternak siap saji (HS 23), Buah dan kacang-kacangan (HS 08), Produk industri penggilingan pati, inulin, gluten dan gandum (HS 11). Hal ini menunjukkan komoditas-komoditas tersebut memiliki keterkaitan perdagangan dengan dunia secara dua arah (two-way trade).

Jika digeneralisasi, perdagangan pertanian Indonesia dan RCEP secara realitas masih sangat lemah yaitu sebesar 19,74, hal ini menandakan impian Indonesia untuk masuk dalam global supply chain masih jauh. 
Rendahnya nilai IIT ini bisa saja disebabkan karena rakyat maupun pemerintah yang masih khawatir dalam kegiatan impor. Padahal jika Indonesia ingin masuk dalam global value chain, impor bukanlah sesuatu yang harus dihindari. Struktur dagang Indonesia yang masih tradisional, masih berpikir jika semua komoditi harus diproduksi sendiri, hal ini menandakan jika impian Indonesia untuk menjadi pemain global masih jauh, karena salah satu parameter perdagangan di negara maju saat ini dapat dilihat dari pola perdagangannya. Aliran perdagangan Indonesia dan RCEP masih menunjukkan perdagangan satu arah, banyak pada komoditi pertanian dimana Indonesia hanya ekspor saja, begitu pula sebaliknya untuk produk lain, Indonesia hanya impor saja. Mayoritas komoditas dengan nilai IIT rendah terdiri 6 dari 24 komoditi pertanian Indonesia, yaitu daging dan jeroan (HS 02), produk hewan (HS 05), bahan anyaman sayuran (HS 14), lemak hewan (HS 15), kokoa (HS 18) dan produk alcohol (HS 22).

Meski IIT Indonesia masih tergolong rendah, namun beberapa negara membantu Indonesia dalam peningkatan kemampuan perdagangan intra industri Indonesia. Malaysia menjadi salah satu bukti perdagangan intra industri itu benar adanya. Malaysia adalah anggota RCEP yang memiliki kondisi geografi dan demografi paling mirip dengan Indonesia, namun Malaysia juga adalah negara anggota RCEP dengan nilai IIT tertinggi. Nilai IIT Indonesia-Malaysia yang tinggi ini menandakan jika Indonesia dan Malaysia saling bergantung dalam perdagangannya. Berbeda dengan Singapura yang kondisi ekonominya sangat dipengaruhi oleh perdagangan internasional, meski $90 \%$ pangannya dipenuhi oleh impor, namun Singapura menduduki ketahanan pangan tertinggi di dunia, menjadi pusat logisitik di dunia dan dengan food security index kedua di dunia setelah Amerika. Singapura memiliki jumlah produk pertanian yang interdependensi terbanyak dengan Indonesia, hal ini disebabkan Singapura yang mengandalkan konsep perantara perdagangan, yaitu dengan membeli barang-barang mentah dari Indonesia dan menyempurnakannya untuk di ekspor kembali.

Thailand menduduki posisi ketiga di ASEAN dan keempat di RCEP untuk nilai nilai IIT dengan Indonesia, menyusul negara ASEAN+5 (Jepang, Cina, Korea Selatan, Australia dan New Zealand). Negara-nagara tersebut 
adalah negara yang bisa menjadi prioritas Indonesia dalam peningkatan perdagangan intra industri untuk produk pertanian karena riwayat perdagangan intra indutri yang tinggi dan banyaknya komoditi pertanian yang sudah terintegrasi.

Setelah melihat negara yang dapat menjadi prioritas perdagangan intra industri, maka selanjutnya dapat diketahui komoditi-komoditi apa saja yang diharapkan dapat memberikan keuntungan bagi perdagangan Indonesia dan RCEP. Pasalnya Indonesia tidak harus mengekspor seluruh komoditi pertanian Indonesia ataupun mengimpor komoditi-komoditi yang tidak bisa menghasilkan manfaat ekonomi bagi Indonesia. Berdasarkan hasil perhitungan IIT masing-masing negara diatas dapat dilihat jika setiap negara memiliki produk pertanian tertentu yang saling terkait dengannya.

Produk-produk pertanian Indonesia yang memiliki prospek dalam perdagangan intra industri dengan RCEP berdasarkan tingginya nillai IIT adalah komoditi hewan hidup (HS 01) yang saling interdependensi dengan Malaysia. Ikan (HS 03) interdependesi hanya dengan New Zealand. Produkproduk yang berasal dari hewan (HS 04) Indonesia saling interdependensi dengan Malaysia, Thailand dan Jepang. Pohon (HS 06) hanya saling interdependensi dengan Cina, sayuran (HS 07) dengan Malaysia dan buahbuahan (HS 08) dengan Korea Selatan. Kopi (HS 09) Indonesia terintegrasi dengan Vietnam dan Cina. Sereal (HS 10) hanya dengan Singapura. Produk industri hasil dari penggilingan pati, gluten dan gandum (HS 11) Indonesia terintegrasi dengan Korea Selatan dan Jepang. Minyak dari biji dan buah (HS 12) memiliki nilai interdependensi tinggi dengan Thailand, Jepang dan Australia. Getah nabati (HS 13) terintegrasi kuat dengan Filipina, Singapura, dan Korea Selatan. Olahan daging dari ikan (HS 16 ), gula (HS 17), olahan tepung (HS 19), olahan sayuran (HS 20), aneka olahan yang dapat dimakan (HS 21), dan limbah industri makanan (HS 23) adalah produk-produk pertanian yang saling interdependensi lebih dari tiga negara RCEP.

\section{KESIMPULAN DAN REKOMENDASI} KEBIJAKAN

Negara-negara anggota RCEP adalah mitra dagang potensial bagi Indonesia, hanya saja rata-rata nilai IIT Indonesia-RCEP sebesar 19,74 ini masih tergolong memiliki integrasi yang rendah. Rendahnya nilai IIT ini bisa saja disebabkan karena Pemerintah dan 
rakyat Indonesia yang masih khawatir dengan impor. Padahal jika ingin masuk dalam global supply chain/global value chain, yang namanya impor bukanlah sesuatu yang harus dihindari, selama impor bisa menjadi bagian dari proses produksi (raw material) untuk diekspor. Struktur dagang Indonesia yang masih tradisional, masih berpikir jika semua komoditi harus diproduksi sendiri, hal ini menandakan impian Indonesia untuk masuk dalam pemain global masih jauh. Meski masih memiliki IIT yang rendah, perdagangan intra industri pertanian Indonesia dengan anggota-anggota RCEP pada periode 2010-2019 memperlihatkan kecenderungan peningkatan.

Banyak produk pertanian yang di ekspor Indonesia memiliki keterkaitan perdagangan intra industri yang cenderung meningkat, terutama dengan Malaysia, Singapura, Thailand, Cina, Jepang, Korea Selatan, dan Australia karena memiliki komoditas dengan integrasi intra industri terbanyak. Banyaknya produk yang menunjukkan kedekatan perdagangan mengindikasikan prospek yang menguntungkan dalam kerja sama perdagangan, semestinya dioptimalkan oleh Indonesia untuk meningkatkan kerja sama perdagangan maupun perekonomian secara keseluruhan. Hal ini menunjukkan bahwa keterkaitan perdagangan Indonesia dengan RCEP untuk produk pertanian di negaranegara tersebut bersifat dua arah (twoway trade). Perdagangan dua arah ini akan memberi kuntungan bagi kedua pihak untuk menjaga kontinuitas ekspor Indonesia, karena perdagangan ini bersifat saling interdepensi yang akan menjaga trade balance meski ada guncangan perdagangan di kemudian hari. Meskipun IIT antara Indonesia dan negara Brunei Darussalam, Kamboja, Laos, Myanmar, Filipina, Vietnam, dan Selandia Baru tergolong rendah, ketiga negara itu mulai menunjukkan peningkatan nilai IIT dalam kurun waktu lima tahun terakhir, dengan promosi yang lebih intensif diharapkan perdagangan intra industri produk pertanian akan menjadi lebih baik.

Komoditas yang memiliki indeks intra industri antara Indonesia dan negara-negara anggota RCEP tertinggi pertama sampai yang ketiga adalah komoditi HS 19 (Olahan berdasarkan sereal, tepung, atau susu; produk pastry), HS 21 (Olahan lain yang dapat dimakan), HS 20 (Olahan sayuran, buah-buahan atau bagian tanaman lainnya). Sedangkan indeks intra industri produk terendah adalah HS 02 
(Daging dan sisa daging yang bisa dimakan). Sebaliknya, komoditas dengan nilai intra industri terendah adalah bahan HS 14 (anyaman nabati).

Berdasarkan hasil perhitungan intra-industry trade, penulis memberi saran agar pemerintah tidak hanya memikirkan bagaimana memenuhi kebutuhan domestik pada barang tertentu, tetapi juga harus fokus pada akibat yang akan ditimbulkan, terutama beban pemerintah pada neraca perdagangan, karena komposisi impor yang terlalu besar bisa menyebabkan rendahnya IIT, diharapkan juga agar Indonesia memperbaiki tingkat integrasi perdagangan Indonesia dan negaranegara anggota RCEP melalui hilirisasi atau melakukan kegiatan pengolahan pada produk-produk pertanian dari Indonesia. Mengekspor komoditas olahan, tidak hanya komoditi dalam bentuk bahan mentah, dapat memberi nilai tambah komoditi Indonesia semaikin tinggi. Pemerintah dapat memberikan kemudahan atau insentif bagi para pengusaha untuk mendirikan industri pengolahan pertanian salah satunya yaitu dengan memberikan keringanan pajak dalam jangka waktu tertentu. Kebijakan yang perlu dilakukan salah satunya adalah dengan fokus pada pola perdagangan Indonesia dengan partner dagangnya, dengan cara mempertahankan komoditaskomoditas potensial dengan partner dagang Indonesia.

Melalui tulisan ini juga penulis ingin menyampaikan gambaran kesiapan Indonesia dalam menghadapi perdagangan intra industri, karena hingga saat ini Indonesia masih memandang buruk kegiatan impor, dimana impor dianggap dapat mengancam stabilitas ekonomi Indonesia. Padahal bisa saja kegiatan impor pada produk tertentu dapat meningkatkam economic of scale dan produk yang terdiferensiasi bagi Indonesia.

\section{UCAPAN TERIMA KASIH}

Penulis mengucapkan terima kasih kepada seluruh redaksi Buletin IImiah Litbang Perdagangan, Mitra Bestari dan seluruh pihak terkait dalam penulisan karya ini atas seluruh kesempatan, kontribusi dan bantuan yang diberikan.

\section{DAFTAR PUSTAKA}

Afriandini, dan Hastiadi, F. F. (2018). Pengaruh Penanaman Modal Asing Jepang Terhadap Perdagangan The Effect Of Foreign Direct Investment On Indonesia-Japan Intra-Industry Trade. Jurnal Ekonomi Dan Pembangunan Indonesia, 51-71.

Alhayat, A. P. (2012a). Analisis Pola Perdagangan Bilateral Indonesia-RRT Sebelum Dan Setelah Implementasi Acfta. Widyariset, 15(1), 99-108.

Alhayat, A. P. (2012b). Analisis Pola 
Perdagangan Bilateral Indonesia-Rrt Sebelum Dan Setelah Implementasi Acfta Indonesia-China' S Bilateral Trade Pattern Analysis ,. Badan Pengkajian Dan Pengembangan Kebijakan Perdagangan, 15(1), 99108.

Amalina, A. A. F., Novianti, T., dan Asmara, A. (2018). Analisis Kinerja Perdagangan Indonesia Ke Negara Potensial Benua Afrika. Jurnal Ekonomi Dan Kebijakan Pembangunan, 7(1), 43-59.

Ambarita, Y. M. R., dan Sirait, T. (2019). Penerapan Model Gravitasi Data Panel: Kajian Perdagangan Internasional Indonesia Ke Negara Anggota Asean (Application Of Gravity Model Panel Data : International Trade Study Of Indonesia To Asean. Seminar Nasional Official Statistics 2019: Pengembangan Official Statistics Dalam Mendukung Implementasi Sdg's., 726-737.

Amir, F., Dedi Budiman Hakim, dan Tanti Novianti. (2020). Dampak Diversifikasi Ekspor Terhadap Pertumbuhan Ekonomi Negara-Negara Anggota Asean. Jurnal Ekonomi Dan Kebijakan Pembangunan, 7(2), 118-139. Https://Doi.Org/10.29244/Jekp.7.2.11 8-139

Andriani, Y., dan Andre. (2017). Implikasi Perjanjian Kemitraan Ekonomi Komprehensif Indonesia-Australia (laCepa) Terhadap Perdagangan Luar Negeri Indonesia. Andalas Journal Of International Studies, 6(1), 79-92. Https://Www.Researchgate.Net/Public ation/324689523_Implikasi_Perjanjian _Kemitraan_Ekonomi_Komprehensif_ Indonesia-Australia_la-

Cepa_Terhadap_Perdagangan_Luar Negeri Indonesia/Fulltext/5add2 2 c974 58515c60f5f2f67/Implikasi-PerjanjianKemitraan-Ekonomi-Komprehe

Astriana, A. A. R. (2015). Analisis Perdagangan Intra Industri IndonesiaCina. Jurnal Administrasi Negara, 21(April), 22-31.

Austria, M. S. (2004). The Pattern Of Intra-
Asean Trade In The Priority Goods Sector. Final Main Report, 006(03), 17.

Ayu, B., dan Wibisono, S. (2017). Penurunan Perdagangan Bilateral Indonesia- Korea Selatan Dalam Kerjasama Working Level Task Force Meeting (Wltfm). Journal IImu Hubungan Internasional, 5(4), 13811396.

Bato, A. R. (2014). Perdagangan Intra Industri Indonesia Dengan Beberapa. Economics, Social, And Development Studies, 1(1), 28-40.

Bojnec, Š., dan Ferto, I. (2016). Patterns And Drivers Of The Agri-Food IntraIndustry Trade Of European Union Countries. International Food And Agribusiness Management Review, 19(2), 53-74.

BPS. (2020a). Pendapatan Nasional (National Income Of Indonesia). In Buku Publikasi Statistik. Https://Www.Bps.Go.Id/Publication/20 20/06/12/7fe8d749c43bad46b160166 2/Pendapatan-Nasional-Indonesia2015-2019. Html

BPS. (2020b). Statistik Pertumbuhan Ekonomi. Berita Resmi Statistik, No. 85/11/(15), 1-12.

Brülhart, M. (2008). An Account Of Global Intra-Industry Trade, 1962-2006. The University Of Nottingham Research Paper Series Globalization, Productivity And Technology., 08.

Cei. (2009). Estimating The Impact Of An Australia-Indonesia Trade And Investment Agreement (Issue January).

DPRRI. (2017). Kunjungan Delegasi Badan Kerjasama Antar Parlemen Dewan Perwakilan Rakyat Republik Indonesia Untuk Menindaklanjuti ResolusiResolusi Organisasi Antar Parlemen Regional Terkait Tantangan Integrasi Regional Dan Liberalisasi Perdagangan (Pp. 1-11).

Dwipayana, I. K. A., dan Kesumajaya, W. W. (2014). Pengaruh Harga , 
Cadangan Devisa , Dan Jumlah Penduduk The Effect Of Price , Foreign Exchange Reserve , And Number Of Population Against Indonesia' S Rice Import. Ekonomi, 3(4), 164-172.

Fajri, D. A., dan Rani, F. (2016). Kepentingan Selandia Baru Melakukan Kerjasama Perdagangan Bebas Dengan Indonesia Dalam Kerangka Aanzfta Tahun 2012-2015. Jom Fisip, 3(2), 1-15.

Fertő, I. (2015). Horizontal Intra-Industry Trade In Agri-Food Products In The Enlarged European Union. Studies In Agricultural Economics, 117(2), 86-92. Https://Doi.Org/10.7896/J.1425

Grubel, G., dan Llyod, P. . (1971). The Empirical Measurement Of Intra- Indus Try Trade. Economic Record, 47, 494517.

Herjanto, E., dan Purwanto, E. H. (2010). Konversi Standar Nasional (Sni) Ke Harmonized System (Hs). Jurnal Riset Industri, IV(2), 41-56.

Hermawan, I. (2017). Analisis Daya Saing Komoditas Pertanian Dan Bahan Pangan Indonesia Di Pasar Kamboja, Laos, Myanmar, Dan Vietnam. Kajian, 22(2), 15-31.

Hikmah, M., Suhadak, dan Nurlaily, F. (2018). Uji Beda Implementasi Asean Australia - New Zealand Free Trade Agreement ( Aanzfta ) Terhadap Ekspor Dan Impor ( Studi Pada Trademap Periode Tahun 2009-2014 ). Jurnal Administrasi Bisnis, 57(2), 31-41.

Hoang, V. (2018). Assessing The Agricultural Trade Complementarity Of The Association Of Southeast Asian Nations Countries. Agric. Ecom, 2018(10), 464-475.

Hoang, V. (2019). The Dynamics Of Agricultural Intra-Industry Trade: A Comprehensive Case Study In Vietnam. Structural Change And Economic Dynamics, 49, 74-82. Https://Doi.Org/10.1016/J.Strueco.201 9.04.004
Hotsawadi, dan Widyastutik. (2020). Diversifikasi Ekspor Non Migas Indonesia Ke Pasar Non Tradisional. Buletin IImiah Litbang Perdagangan, 14(2), 215-238.

Indonesia.go.id. (2019) Progres RCEP, Keluarnya India, Dan Peluang Indonesia. Downloaded on 30 Maret 2020 dari Https://Www.Indonesia.Go.Id/Narasi/l ndonesia-Dalam-

Angka/Ekonomi/Progres-RcepKeluarnya-India-Dan-PeluangIndonesia.

ITPC. (2018). Food Preparation Hs 2106. In Laporan Informasi Intelijen Bisnis. Http://Publications.Lib.Chalmers.Se/R ecords/Fulltext/245180/245180.Pdf\%0 ahttps://Hdl.Handle.Net/20.500.12380/ 245180\%0ahttp://Dx.Doi.Org/10.1016/ J.Jsames.2011.03.003\%0ahttps://Doi. Org/10.1016/J.Gr.2017.08.001\%0ahtt p://Dx.Doi.Org/10.1016/J.Precamres.2 014.12

Jiuhardi. (2016). Kajian Tentang Impor Daging Sapi Di Indonesia. Forum Ekonomi Fakultas Ekonomi Dan Bisnis Universitas Mulawarman, 17(2), 7591.

Https://Media.Neliti.Com/Media/Public ations/55382-Id-Kajian-TentangImpor-Daging-Sapi-Di-Indo.Pdf

Kemendag. (2010). Kajian Kelayakan Pembentukan Fta Indonesia - Mesir. In Laporan Akhir 2010 (Pp. 117-125).

Kemendag. (2019). Selayang Pandang Rcep (Pp. 1-8). Kementerian Perdagangan.

Kemendag, B. P. Dan P. K. P. K. (2016). Kinerja Ekspor Produk Pertanian Indonesia Di Pasar ASEAN.

Kemenperin. (2020). Laporan Informasi Industri Buku Industri. Http://lkapi.Org/News/Detail/IndustryInfo/24/Informasi-Industri-BukuIndonesia.Html

Kementan. (2020). Statistik Ketenagakerjaan Sektor Pertanian (Februari 2018). 
Krugman, P. R. (1979). Increasing Returns, Monopolistic Competition, And International Trade. Journal Of International Economics, 9(4), 469479.

Łapińska, J. (2016). Determinant Factors Of Intra-Industry Trade: The Case Of Poland And Its European Union Trading Partners. Equilibrium, 11(2), 251.

Https://Doi.Org/10.12775/Equil.2016.0 11

Li, L. (2017). The Impact Of Intra-Industry Trade On Business Cycle Synchronization In East Asia. China Economic Review, 45(July), 143-154. Https://Doi.Org/10.1016/J.Chieco.201 7.07.004

Lipsey, Richard G. (1995). Pengantar mikroekonomi. Jakarta: Bina rupa Aksara

Madiah, S., dan Widyastutik. (2020). Fasilitasi Perdagangan Dan Ekspor Manufaktur Unggulan Indonesia Ke Rcep. Jurnal Badan Pendidikan Dan Pelatihan Keuangan Kementerian Kuangan Republik Indonesia, 13(1), 15-32.

Mayadewi, A., dan Purwanti, P. A. P. (2020). Analisis Perbandingan Ekspor Dan Impor Komoditi Unggulan Indonesia-China Sebelum Dan Setelah Fakultas Ekonomi Dan Bisnis Universitas Udayana ( Unud ), Bali, Indonesia Pendahuluan Setiap Negara Memiliki Sumberdaya Baik Sumberdaya Alam Maupun Sumberdaya Ma. Ekonomi Pembangunan Universitas Udayana, 9(1), 31-60.

Mikic, M., dan Gilbert, J. (2009). Trade Statistics In Policymaking. Http://Www.Unescap.Org/Resources/ Trade-Statistics-PolicymakingHandbook-Commonly-Used-TradeIndeces-And-Indicators-Revised

Nguyen, H. M., Quan, B. Q. M., Le, H. Van, dan Van Tran, T. (2020). Determinants Of Intra-Industry Trade Between Vietnam And Countries In Tpp. Journal
Of Asian Finance, Economics And Business, 7(1), 123-129. Https://Doi.Org/10.13106/Jafeb.2020. Vol7.No1.123

Ningsih, E. A., dan Kurniawan, W. (2016). Daya Saing Dinamis Produk Pertanian Indonesia Di Asean (Dynamic Competitiveness Of Indonesian Agricultural Products In Asean). Jurnal Ekonomi Kuantitatif Terapan, 9(2), 117-125.

Nizar, M. A., dan Wibowo, H. (2007). The Analysis Of Indonesia ' S Trade Pattern With Some Asia Countries: Intra-Industry Trade ( lit ) Approach. Munich Personal Repec Archive Trade, 1(66323).

Nuryanti, S. (2010). Peluang Dan Ancaman Perdagangan Produk Pertanian Dan Kebijakan Untuk Mengatasinya : Studi Kasus Indonesia Dengan Australia Dan Selandia Baru Bilateral Trade Challenge And Opportunity Of Agricultural Products Between Indonesia And Australia And New Zealand. Analisis Kebijakan Pertanian, 8(3), 221-240.

Parmadi, Zulgani, dan Emilia. (2018). Daya Saing Produk Unggulan Sektor Pertanian Indonesia Dalam Hubungannya Dengan Pertumbuhan Ekonomi. 13(2), 77-86.

Plummer, M. G. (2010). Methodology For Impact Assessment Of Free Trade Agreements Methodology For Impact Assessment Of Free Trade Agreements.

Retnosari, L. N. (2018). Trade Complementarity Dan Export Similarity Serta Pengaruhnya Terhadap Ekspor Indonesia Ke Negara-Negara Anggota Oki Trade Complementarity And Export Similarity And Its Impact On Indonesia' $S$ Export To The Oic Member Countries Pendahuluan Dalam Nasional. Buletin IImiah Litbang Perdagangan, 12(1), 21-46.

Sari, P. G. A. (2018). Dampak Keunggulan Komparatif Dan Kerjasama AseanAutralia-New Zealand Fta (Aanzfta) 
Terhadap Perdagangan Indonesia. In Interciencia.

Satriana, E. D., Harianto, dan Priyarsono, D. S. (2019). Pengaruh Volatilitas Nilai Tukar Terhadap Kinerja Ekspor Utama Pertanian Indonesia. Buletin IImiah Litbang Perdagangan, 13(2).

Sawyer, W. C., Sprinkle, R. L., dan Tochkov, K. (2010). Patterns And Determinants Of Intra-Industry Trade In Asia. Journal Of Asian Economics, 21(5), 485-493. Https://Doi.Org/10.1016/J.Asieco.201 0.04.001

Sun, Z. Lu, dan Li, X. De. (2018). The Trade Margins Of Chinese Agricultural Exports To Asean And Their Determinants. Journal Of Integrative Agriculture, 17(10), 2356-2367. Https://Doi.Org/10.1016/S20953119(18)62084-2

Susanto, D. A. (2019). Isu Standar Pada Perdagangan Indonesia-Australia Dalam Kerja Sama lacepa. Buletin IImiah Litbang Perdagangan, 13(1), 21-46.

Https://Doi.Org/10.30908/Bilp.V13i1.3
34

Trademap. (2021). Data Ekspor dan Impor Kelompok Komoditas Pertanian Indonesia dan Negara-Negara RCEP. Diunduh pada Juni 2020 melalui https://www.trademap.org/Index.aspx

Widarjono, A. (2009). Indonesia's IntraIndustry Trade With Asean. Jurnal Ekonomi Pembangunan, 13, 61-70.

Yu, C., dan Qi, C. (2015). Research On The Complementarity And Comparative Advantages Of Agricultural Product Trade Between China And Cee CountriesdanLt;Br/danGt;-Taking Poland, Romania, Czech Republic, Lithuania And Bulgaria As Examples. Journal Of Service Science And Management, 08(02), 201-208. Https://Doi.Org/10.4236/Jssm.2015.82 022

Zhang, Y., dan Clark, D. P. (2009). Pattern And Determinants Of United States' intra-industry trade. International Trade Journal, 23(3), 325-356. https://doi.org/10.1080/088539009030 12310 